\title{
THE DAUGHTER OF THE WORD: WHAT LUTHER LEARNED FROM THE EARLY CHURCH AND THE FATHERS
}

\author{
GLEN L. THOMPSON* \\ Asia Lutheran Seminary
}

\begin{abstract}
All the major sixteenth-century Reformers knew something about the early church and used the early Fathers. As an Augustinian monk and professor of theology, however, Luther's knowledge and use of the great Father was both deeper and more nuanced. While indebted to Augustine, Luther went further in defining what it meant for theology to be 'scriptural'. He saw history as the interaction of God's two regimes, and the church of every age as weak and flawed but conquering through the cross of Christ. This led him to a free use of the Fathers without being constrained to always agree with or imitate them. The comfort he received from the Apostles' Creed in particular led him to appreciate the early creedal statements, and so it was natural for him to use them as models when formulating the new confessions required in his own day. The sixteenth-century heritage of written confessions of faith is a heritage under-appreciated but still vital for church bodies today. ${ }^{1}$
\end{abstract}

KEYWORDS: Luther, Augustine, Church Fathers, History, Creeds, Confessions

Ecclesia enim est filia, nata ex verbo, non est mater verbi. 'For the Church is the daughter born from the Word; she is not the mother of the Word.' Luther, Lecture on Genesis 7:17-24

(AE 2: 101; WA 42: 334)

In January of 1505, the 21-year old Martin Luther was promoted to Master of Arts at the University of Erfurt. By May he had begun his doctoral studies in secular law while lecturing undergraduates. By mid-summer, however, the spiritually-troubled young Master gave it all up and entered a monas-

* GLEN L. THOMPSON (PhD 1990, Columbia University) is Academic Dean and Professor of New Testament and Historical Theology at Asia Lutheran Seminary. Email: Glen.Thompson@als.org.hk.

1 All English citations of Luther's writings, unless otherwise specified, are taken from the 54-volume American Edition of Luther's Works (AE); where no English translation was available, I have supplied my own and I give reference to the authoritative German Weimar Edition (WA, WBr, WTr). 
tery. In the seven years that followed, he was ordained a priest, taught at both Erfurt and Wittenberg universities, and studied theology intensively, being promoted to Doctor of Theology in October of 1512. Therefore, it can surprise no one that the future reformer would have an intimate knowledge of the Roman Catholic Church's traditions and teachings. However, although the Renaissance had begun bringing to light the resources of the early church through the study of Greek, and editions of the early Greek and Latin Fathers began appearing through the agency of the stillnascent printing industry, theological study in Luther's day was still primarily the study of the Medieval Glossa ordinaria, canon law (especially Gratian), and the scholastic masters-Lombard, Dun Scotus, Aquinas, and Bernard, to name just a few. So, it is legitimate for us to ask both just how much Luther did learn about the foundational centuries of the church and its leading writers, and what he learned from such study. We can then assess how valuable this was for the work and legacy of both the reformer and his reformation.

\section{The Early Augustinians}

We see the first glimmer of Luther's interest in the early church when he intentionally chose to enter the Augustinian Order of Hermits. Yet the great bishop of Hippo was not the first father to have made a deep impression upon him, but rather Athanasius of Alexandria. Already during his first year, while still a novice, he became familiar with a dialogue between Athanasius and Arius and came to admire the former's stand for doctrinal truth. In actuality, the dialogue was the composition of Vigilius of Thapsus from a century later and was falsely attributed to Athanasius (Beer and von Stockhausen 1999). But the impression was deep and lasting, and Luther cited this work numerous times over the course of his career. In 1532, Luther's admiration of Athanasius would still be evident (and he would mention the Dialogue yet again) in the introduction he wrote for his friend Bugenhagen's edition of Athanasius's Contra gentes (Luther 1532: 530-532).

It was the great bishop of Hippo, however, who would become and remain the most influential and oft-quoted church Father throughout Luther's life. Veit Dietrich quotes him as saying, 'At first I devoured, not merely read, Augustine' (Luther 1532: 49). His own annotations in the margins of a volume of Augustine's writings (Opuscula plurima, Strassburg 1489) prove that as early as 1509 , Luther was absorbed in the works of the great African bishop. There were several reasons for this. First of all, the works of this Father were regularly used in the theological and spiritual training of the German monks named after him. By 1516 Luther had progressed at least as far as the eighth volume of the Opera omnia of Augustine (Basel 1506), as he writes in a letter to George Spalatin (Luther 1516: 24). The 
young Augustinian monk was in the right location to access this first attempt at a complete edition of the bishop of Hippo's works.

Secondly, Luther's confessor and mentor, Johann von Staupitz, was himself heavily influenced by Augustine in his own life and theology. Appointed by Frederick the Wise as the first provost (Probst) of Wittenberg University upon its foundation in 1502, Staupitz ensured that Augustine became patron saint both of the theological faculty and of the university as a whole (Posset 2003: 71, 74). This is where Luther was destined to spend his entire career. Furthermore, from 1503 on Staupitz also served as vicar general for the Observant Augustinian monasteries in Germany. In this position, he oversaw the studia generalia, the training programs used by the order to train priests from among its members. Staupitz's own Augustinian theology may have tinged the curriculum which Luther completed in his own study for the priesthood in Erfurt; and Luther himself was assigned in 1512 to oversee the studium generale in Wittenberg after his move there.

Yet neither of these reasons suffice. The study of Augustine was not a mandatory part of the Augustinian rule (Obermann 1989: 161); nor did all Staupitz's associates or disciples become Augustine scholars. Already, in 1516, he would write (somewhat hyperbolically): 'Devotion to my Order does not compel me to approve of the blessed Augustine; before I had stumbled upon his books I had no regard for him in the least' (Luther 1516: 24). It was both Augustine's approach to theology and his answers which created sympathetic vibrations when the young Luther opened the bishop of Hippo's writings. It was Augustine who taught Luther that good theology is the product of a heart-felt spiritual quest for answers combined with careful and prayerful biblical exegesis. The young monk was tormented by the question of how a wretched sinner could find forgiveness before a righteous God. While Augustine's writings did not answer this question to the young professor's satisfaction, they began pointing him in the right direction. Later, after he found the answer through his own struggle with the scriptural texts, Luther read Augustine's The Spirit and the Letter and rejoiced that Augustine also had come to understand that it was the righteousness of Christ 'with which God clothes us when he justifies us' (Luther 1545: 337).

The breadth of his early acquaintance with the Fathers is revealed in that early letter to Spalatin in which he asks his friend to contact Erasmus and point out to him that he is depending too much on Jerome's interpretations. As a result, he writes, Erasmus is neglecting Augustine whose theology is not 'of his own wisdom but is rather that of the most outstanding Fathers, such as Cyprian, [Gregory of] Nazianzus, Reticius [of Autun], Irenaeus, Hilary, [Methodius] Olympius, Innocent, and Ambrose' (Luther 1516: 24). However, since fragments of the works of Reticius and Methodius have 
survived only as citations in the works of other Fathers, we should not assume Luther had read all of these first hand. Two years later Luther would state in his introduction to the German Theology of Johannes Tauler that "no book except the Bible and St. Augustine has come to my attention from which I have learned more about God, Christ, man, and all things' (Luther 1518: 75). Earlier the same year he had written again to Spalatin, 'If you like my course of study, begin by reading Augustine's On the Spirit and the Letter ... Then take the book Against Julian and likewise the book Against the Two Letters of the Pelagians. Add blessed Ambrose's work on the calling of all heathen, although this book appears... to have been written by someone other than Ambrose... If these suggestions appeal to you, I shall send you more later on' (Luther 1518b: 54).

Thus, we see that from the very beginning Luther used the Fathers critically. This can be seen in an incident in 1516 involving his colleague Andreas Bodenstein von Karlstadt, the senior theology professor at Wittenberg. In a debate that centered on Augustine, Luther showed that a tract on True and False Penance did not agree with Augustine's theology and therefore could not have been penned by him. This drove Karlstadt to a deeper study of Augustine and he became in certain respects a more faithful Augustinian than Luther himself' (Steinmetz 1881: 123-124). Luther would not be put into a theological straight-jacket even by the writings of Augustine himself. Yet Oberman can still describe Luther's approach to theology as 'an unusual medieval alliance between Augustinianism and nominalism' (Oberman 1989: 161).

\section{The Early Church and Luther's View of History}

Luther's knowledge of the Church Fathers, as well as several of Luther's well-known emphases, become entwined in his view of history in general, and, therefore, also in his broader evaluation of the early church. The first is his concept of the hiddenness of God in the playing out of history; a second is his understanding of the two 'regimes' which make up God's creation; a third is Luther's strong belief in the divine vocation given to Christians in all walks of life. The result is that Augustine's 'two cities' image is developed into a more complex metanarrative.

Luther stresses that God chose to conceal himself in the historical process, and thus invisibly oversees the created world through two 'regimes' (German-Regiment). These two entities can be thought of as God's two hands, working separately and in different ways but not opposed to each other. The first is the worldly regime (politia) by which God uses the natural means of government, the family, and other institutions to direct, manage, and order the outward course of world history. In that regime, man serves as a cooperator Dei when he functions within his secular vocation using his 
God-given human reason. In this function both institutions and individuals serve as masks for God's hidden operation. The religious or spiritual regime (religio), on the other hand, is that by which God oversees salvation history. In this realm, he works not through human reason, but through the humiliation of the cross and via the Means of Grace (the preached Word and the Sacraments). While the worldly regime is outwardly visible, the spiritual one is apprehended solely by faith. Every human being lives in both regimes simultaneously, and the Devil uses all his power to pervert and stymie these regimes and confuse them in the minds of men.

These regimes are also distinct from the 'two kingdoms'-that of the Devil who controls the unconverted in the world, and that of Christ and all his true believers. Every human belongs to but one of these realms. While the depiction of these two kingdoms has close parallels with Augustine's understanding of the two cities, the concept of the two regimes appears to come more directly from Luther's own study. Headley's first chapter (1963), replete with citations and references, is essential reading for understanding the further nuances of Luther's view of history. With these concepts as background, one can understand that Luther's view of the early church and the role of the Fathers would itself be complex.

For Luther, the Fathers provided excellent illustrations of the Christian's struggles within the two regimes. They were pointedly not exemplars to imitate in all details of their doctrine or devotional life. He did not come to this conclusion merely because of his growing aversion to the veneration of saints and their relics, something common among all the reformers. Rather, as John Headley notes, it was because Luther firmly believed that 'any imitation of a saint or great religious figure not only obscures the redemptive action of Christ but leads inevitably to a fatal righteousness from good works' (Headley 1963: 50). Each Christian, including the Fathers, has a God-given vocation which he is to live out faithfully to the best of his ability. However, Augustine's vocation is not mine, and Jerome's is not yours. As Luther put it when speaking of Daniel, his holy life 'should not be followed as an example in these things, but should be avoided as sheer miracles, which merely deserve praise and honor. For God does not desire to perform miracles in the fiery furnace for every single one of us; nor is it his will to make a Bernard, a Francis, a Gregory, a Benedict, or an Augustine out of each one of us' (Luther 1522: 192).

Luther did see great value in the Fathers and the early councils as historical witnesses to scriptural teaching. They too were masks of God in his spiritual regime when they faithfully witnessed to the gospel message. In his mature work On the Councils and the Church (1539), Luther makes this point clear. The main value of the early councils was not that they served as authoritative assemblies, but rather that they witnessed to the scriptural teach- 
ing that the early church shares with us. In the first half of the treatise, he argues that councils have no authority to establish new articles of faith, to command specific good works, to impose ceremonies, or to interfere in secular governmental affairs (i.e., take part in God's first regime). On the other hand, they did have the duty to condemn and suppress new articles of faith, evil works, and ceremonies that conflicted with Scripture, and they could legitimately institute ceremonies that were useful and profitable to the church.

\section{Shortcomings of the Fathers}

The conception of God's divine but hidden direction of history allowed Luther in his 1539 opus on the councils to face head on several crucial weaknesses in both the early Fathers and the councils. First of all, they were so obviously fallible. At times, they were inconsistent, and at other times they were totally contradictory. This was no new insight of Luther's. After all, as Luther himself points out, Gratian had named his great twelfth-century collection of canon law Concordia discordantium canonum (Harmonization of the Disagreeing Canons) (Luther 1539: 20-21), and Peter Lombard's Sentences attempted a similar project with theology in general. As we know, both attempts ended in synchronizations to the image of medieval Roman Catholicism. Many well-meaning attempts by modern Protestants to appropriate the Fathers end with equally distorted images as a result of their own theological cherry-picking. Headley rightly concludes: 'The significance of Luther's consideration of the papal decretals lay not in any overthrow of canon law or the magisterium of the Roman Church, for such was not his intention at this juncture; it lay in his effort to preserve the integrity of Scripture and to assert its sufficiency as a single ground and source of authority by which conflicting authorities might be measured' (Headley 1963: 80).

Secondly, Luther pointed out that if we are to honor the Fathers properly, we should also honor their own warnings against accepting as ultimate authorities their own works or any opinions apart from Scripture. Augustine was the supreme role model here. Luther gives two quotes from a letter of Augustine to Jerome in this regard: 'I have learned to hold the Scriptures alone inerrant. Therefore, I read all the others, as holy and learned as they may be, with the reservation that I regard their teaching true only if they can prove their statements through Scripture or reason.' And, 'Dear brother, I hope that you do not expect your books to be regarded as equal to those of the Apostles and Prophets' (Augustine, Ep. 82.3; Luther 1539: 25). Luther came across the first of these quotes in Gratian's Decretum and it was there that he found a further statement of Augustine in the preface to On the Trinity (3.2): 'My dear man, do not follow my writing as you do Holy Scripture. Instead, whatever you find in Holy Scripture that you did not 
previously believe, believe it without doubt. But in my writings, you should regard nothing as certain that you were uncertain about before, unless I have proved its truth' (Decretum, Dist. 9, c. 5). Furthermore, the inconsistency and fallibility of the Fathers was further illustrated by Augustine's Retractiones, the book he wrote in later life to supply corrections and additions to his earlier writings.

A third weakness of the Fathers and councils was their incompleteness. Luther says that one cannot efficiently cull all Christian teaching from the Fathers and councils. They tend to deal with the issues, problems, and controversies of their own day, rather than the whole counsel of God which is found in Scripture (Luther 1539: 52). Since we do have Scripture, this weakness of the Fathers is not fatal for us and for our salvation, he notes. Yet this incompleteness in knowledge of the Fathers and councils was especially telling in his own generation. Early printed editions of various Fathers were appearing throughout his lifetime, but there were still many gaps and many poor editions. The same could be said of the early church historians.

Luther himself, while increasingly interested in the early church as his career progressed, seems to have depended for a connected picture of the period almost solely on the history of Eusebius for the first three centuries, and on the Tripartita, the Latin translation of portions of Socrates, Sozomen and Theodoret, for his knowledge of the fourth century. Thus, when surveying the four early Ecumenical Councils, he has to admit that he has rather limited information on the first two, and even less on the third and fourth (both occurring in the fifth century) (Luther 1539: 106-107).

Yet even if he had possessed the more critical and complete editions of the Fathers that we have today, Luther would still have repeated this criticism of incompleteness. For Luther, true theology had to center on Christ's salvific work, the proper distinction and use of law and gospel, and an understanding of the theology of the cross as the theological essentials of the church's kerygma. While these can all be found in the Fathers, they are not found as consistently and as abundantly as one would like. This weakness is evident yet today when one consults the wonderful multi-volume resource entitled Ancient Christian Commentary on Scripture. While it seeks to gather the 'best' quotations from the Fathers on each section of Scripture, the excerpts on some key gospel passages contain little gospel in their exposition and application. This of course, would have come as no great shock to Luther, for he often expostulated on how every Christian, himself included, still had the natural human penchant for the opinio legis-the sinful inclination to let the law rather than the gospel predominate in one's heart, mind, and life. Luther constantly opined that we must all be constantly battling that urge, and often will lose; and so, the early Fathers were no different from us in 
having to fight (often unsuccessfully) that battle as well. Again, the Christians of the past served as object lessons rather than models.

Such 'flaws' in the early church, as well as its spiritual triumphs, were something that Luther was never afraid to use as illustrations and admonitions in his preaching and teaching. He was free to use any Father of any period, or equally free to disregard them. As he said in 1521 in his debate with Latomus, 'the fathers are to be tested by the judgment of the divine Scriptures so that it may be known who has clarified and who has obscured them. Thus, Paul orders us to "test everything; hold fast to what is good"... He commands that all be tested and that there be no exceptions-neither Augustine, nor Origen, nor any man, not even the Antichrist, the pope' (Luther 1521: 217). The inconsistencies of the Fathers were a warning about their use, not necessarily a prohibition, as he pointed out when the reformer Martin Bucer attacked him: 'As is known to the whole world, we do not condemn the statements of the fathers, even if they conflict with one another ([though they do] not [conflict] at this point), as long as they are not quoted to oppose true piety' (Luther 1528: 200). Martin Schulze says that by this method of using the Fathers, Luther 'rendered an inestimable scholarly service to the church, to theology, and to historiography: he freed the Fathers from tradition. At long last it was possible for them to be mistaken' (Schulze 1996: 625).

\section{Understanding and Using History}

One result of Luther's conviction about the clarity and sufficiency of Scripture was that Scripture could be its own interpreter, and 'insofar as Scripture was the Word of God, the Church existed as its creature' (Headley 1963: 80). So, as the opening quotation indicates, the Word is supreme and infallible, the invisible Church is its holy offspring, and the visible church is but the latter's pale and still-flawed image. But this did not stop Luther from using the early church in his argumentation in support of scriptural theology. Already at the Leipzig debate in 1519 he put forth a historical argument that the Fathers, the ecumenical councils and the most accurate church histories all showed that papal primacy was not an ancient divinely appointed doctrine but was the result of canonical legislation originating in the previous four centuries, i.e., the late Middle Ages (Headley 1963: 44-45; Koehler 1900: 363). In the process, he continued to show his historical acumen, seeing a Pseudo-Dionysian canon attributed to Anacletus as a medieval forgery, reasoning that a majority of bishops did not ensure truth since at one period the Arian clergy had such a majority at councils, and the like. He went so far as to call history 'the mother of truth' (Luther 1519: 289; Headley 1963: 45). Such a statement must be interpreted within Luther's larger understanding of history (as described above) by which he viewed 
history as one of the masks behind which God controls all things. Thus, those with the vocation of historian must be held to the highest of standards: 'For since histories describe nothing else than God's work, that is, grace and wrath, it is only right that one should believe them, as though they were in the Bible. They should therefore indeed be written with the very greatest diligence, honesty, and truthfulness' (Luther 1538: 277-278). Such thoughts only grew within Luther over the course of his lifetime, and they explain why he published several chronological tables of world events in his later years.

Luther's nuanced view of church tradition was thus formed by melding his historical sensibility with his biblical and theological Weltanschaung. He approached early church customs and practices, and disputed doctrines, from his 'big picture' of history. Any doctrines or traditions which were contrary to the teachings of Scripture, or interfered with a devotional life that had Christ and his cross at its center, had to be rejected. On the other hand, other customs which had no direct biblical antecedents but which supported Christian devotion could be retained. This position led to the Lutheran church's preservation of customs that were labeled by Anabaptist and Reformed camps as 'popery'. For them purity could only come from a radical break with all man-made rites, images, and practices.

Luther saw such attitudes as a misunderstanding of the authority of the Word and of the Church. In mid-1530 Luther waited at the Coburg Castle, just within the safety of Saxony, as messages were ferried back and forth between him and Philip Melanchton, the head of the Lutheran delegation at the Diet of Augsburg. The milder Melanchton still had hopes of an agreement with the Roman church, if only a few concessions to tradition were made. Luther responded to him as follows:

I might inquire what these pious or permitted observances are which are necessarily established by traditions; you would answer--the Eucharist, the ordering of religious life, etc. But these have long been established by the divine Word. For God prescribes praying, preaching, giving thanks, disciplining the flesh, instructing the people and boys. List for me then some other works subject to traditions. Will you offer purgatory, pilgrimages, brotherhoods, the cult of saints? These indeed are beyond the Word of God and at the same time also impious (Luther 1530: 525-526; trans. of Headley 1963: 91-92).

This, then, is why Luther could view some church tradition as 'scriptural'. His version of sola Scriptura was not limited solely to what was specifically taught in Scripture, but it could include all the customs and practices that were in agreement with Scripture.

This is also what allowed him to retain teachings such as infant baptism while admitting that there is no single statement in Scripture one can point 
to as confirmation. Yet, for Luther as for Lutherans yet today, the practice is $100 \%$ 'scriptural' because it follows from all the other teachings of Scripture (original sin, that all need salvation) without the need to invent new teachings (an age of accountability, the necessity for a human decision). In the same way as those who rightly preach the gospel continue in the succession of the Apostles, so they can develop new customs which assist Christians in leading a pious and godly life. He proclaims later in a sermon:

Therefore, although [Christ] has ascended to heaven and no longer personally or physically preaches on earth, he has not yet nor will in the future cease speaking through the Apostles and their successors; nor will he stop extending his Gospel ever farther and farther and working powerfully in it by means of the Holy Spirit (Luther 1535: 196).

While Luther hit out hard against the new revelations of the Anabaptists, such new revelations were not to be confused with customs that had grown out of the biblical faith of the church. Luther often clearly equates the proliferation of heresies with the multiplication of human traditions. But useful and pious traditions that undergird the simple gospel message should not be thrown out in an attempt to start from scratch. That would truly be dishonoring the Fathers.

\section{Creedal Christianity, Sixteenth-Century-Style}

Among the most important traditiones (things handed down) from the Fathers were the Creeds. The Nicene Creed was the central creed of the Roman Catholic liturgy in the sixteenth century, but it was the Apostles' Creed that Luther first seized upon in his spiritual struggles. Already in his first years in the Erfurt monastery, the Apostles' Creed, recited by the Augustinians in the prime and compline services, brought him comfort. He meditated deeply on the connection between 'the holy Christian church, the communion of saints' and 'the forgiveness of sins' (Koehler 1900: 77-78). When in a Latin sermon on the Creed in 1523, Luther turned to the ecclesiam catholicam, communionem sanctorum, he glossed ecclesiam with Christenheit, rather than Kirche; for Christ's kingdom consists in 'the entire multitude of Christians' and 'all the faithful around the world', i.e., those made faithful by the Holy Spirit (Luther 11: 53). One might say that Luther's great Reformation conversion over the coming decade involved finding the correct relationship between Christ, the Church and the forgiveness of sins.

When Luther issued the forerunner of his Small Catechism (the first evangelical catechism published in Europe) in 1520, it included explanations of the Ten Commandments, the Lord's Prayer, and the Apostles' Creed (rather than the more well-known Nicene Creed). This creed was not chosen because Luther believed the legend of its Apostolic origin, thus pre- 
ferring it to the conciliar origin of the Nicene Creed. Yet he placed it side by side with the commandments and Lord's Prayer which both came directly from Scripture. Luther also came to believe that 'the communion of saints' was an early gloss on the holy Christian church and thus a later addition to the text. He argued for this interpretation in part after reading Rufinus' Expositio symboli which does not mention the phrase (Koehler 1900: 86). Thus it was, beginning with Luther's Catechism, that the Apostles' Creed came into liturgical and catechetical use not just by Lutherans, but by Anglicans as well.

It is instructive to note, however, the somewhat surprising 1538 booklet of Luther entitled The Three Symbols or Creeds of the Christian Faith. This straightforward title is followed by the Apostles' Creed, the Athanasian Creed, and the Te Deum (which was used by Ambrose and Augustine, and sung at the latter's baptism, according to Luther's introduction). After his one-page introduction, the three texts are given (6 pages) followed by a combined explanation of their teaching (20 pages). The Nicene Creed was then added at the very end with the simple comment: 'Let us in conclusion add to these three symbols also the Nicene Symbol, which, like the Athanasian, is directed against Arius. It is sung in the mass every Sunday' (Luther 1538b: 228). Thus, the beautiful early liturgical hymn that Luther treasured was seemingly elevated to equal status with two of the ecumenical creeds (perhaps for its pedagogical value?), while the Nicene Creed is presented more as an afterthought. This illustrates Luther's open attitude towards harvesting the fruits of the church's orthodox heritage.

However, it appears to have been Luther's acquaintance with the early creeds that began the development of one of the Reformation's most important inheritances from the early church-not only adopting the Three Ecumenical Creeds as their own, but also the idea that creedal statements of faith were important tools in defining, confessing and preserving the Scriptural faith of the Church. In the early church, the one 'rule of faith' had been formulated differently by different Fathers. By the fourth century, though, it was necessary to agree on precise creedal statements that could be accepted by the entire orthodox church. These creeds became models for taking the various teachings of Luther and his compatriots and unifying them into more elaborate sixteenth-century apologetical statements. If the Creeds could be used to catechize the faithful, even children, about the difference between the true Christian faith and heretical positions like Arianism and Monophysitism, could not doctrinal statements also be written to ward off the sixteenth-century equivalents of the Arians?

While the Ninety-Five Theses against indulgences may have started the avalanche which shattered the Medieval Roman Catholic Church, it was not the foundational event of the Reformation Church, at least when viewed 
through Lutheran eyes. Lutherans consistently choose June 25, 1530 as the birthdate of their church. They do so in full knowledge that the church of electoral Saxony had been, in effect, Lutheran for almost a decade before then, experiencing a slow and reasoned implementation of evangelical practices, the disappearance of monasteries, and the replacement of priests with newly trained pastors. But it was the public reading of the Augsburg Confession, with its written declaration and explanation of the primitive 'rule of faith' as it applied to the sixteenth-century church, that became the central symbol of Lutheranism (in both senses of the term, i.e., as a creedal statement [Latin symbolum] and as the most iconic Lutheran document).

Understanding the development of this central confession sheds light on how Luther and his colleagues used the model of the early Church Fathers in creating their own creedal statements. In 1526 a diet at Speyer had established an uneasy religious status quo in Germany that allowed Lutheran princes to at least temporarily permit Lutheran teaching within their own borders. But a follow-up meeting at Speyer in the spring of 1529 ended that agreement and promised harsher action against the opposition groups as well as the swift calling of a more general council to close the matter. This forced the reformers to prepare for battle, theologically and politically. In the fall of the year Luther and his colleagues drew up a list of their chief 'articles' of faith, especially as they related to the Swiss reformers, and these Schwabach Articles were adapted for discussions with Zwingli, Bucer and others at Marburg. Early the following year, in preparation for the Diet of Augsburg, Luther and his co-theologians drew up a similar list of twelve Torgau Articles that addressed the commonalities and differences they had with the Catholic position. As stated earlier, due to the inability of the outlawed Luther to leave Electoral Saxony, Philip Melanchthon headed the Lutheran theological delegation at Augsburg. It was he who made use of both the form and content of these two sets of articles in composing the Augsburg Confession.

The time-honored form of theses, which was familiar to all the Lutheran theologians from their university duties, was not used in any of the doctrinal statements produced at these convocations of 1529-1530. The time for debate had passed. Instead they developed a more systematic series of articles that elaborated theological statements of faith. The root meaning of articulus is 'a joint connecting various parts of the body' and then it assumes the more figurative meaning of a member or part of any larger whole. Thus, each article of faith delineated in the Augsburg Confession was seen as part of the larger body of doctrinal truth. The first group of twenty-one articles was entitled Articuli fidei praecipui (the chief articles of faith); the second section contained an additional seven entitled Articuli in quibus recensentur abusus mutate (articles reviewing the abuses that have been corrected). 
While this Confession failed to achieve unity with the Catholics, its form worked admirably to define the Lutheran 'rule of faith'. As a result, Melanchton's lengthier defense (Apology) of the following year followed the same format. A few years later Luther himself penned the Smalcald Articles (1537); the final great Lutheran confession of the sixteenth century, the Formula of Concord (1577), would use an analogous form. The connection with the early creedal statements was retained throughout this period, which is seen in the Formula of Concord's beginning each article with affirmative statements, and ending with anathemas-clear and forceful rejections of false teachings. Such statements reflect the initial closing paragraph of the Nicene Creed and other creeds that followed.

The Augsburg Confession's form would in turn serve as a model for Archbishop Cranmer when he drew up his Thirteen Articles (1538) for use in doctrinal discussions with the Lutherans. Later he expanded these into the Forty-Two Articles (1553). After his death, these were re-worked into the Thirty-Nine Articles (1571), the confession that has remained the central doctrinal statement of the Anglican church. Similar confessions were produced by the Presbyterians (Westminster Confession, 1647), the Baptists (London Baptist Confession, 1644/1646), the Methodists (Articles of Religion, 1784), and other groups that were descendants of the Reformation.

Both the use of and the imitation of the early creeds, while not distinctively Lutheran, was pioneered by the Lutheran camp and fit exactly their theological view of the proper use of the early church, its Fathers, its councils, and its history. God's hidden hand could be seen only in retrospect in all that had happened. Just as the early Fathers provided countless examples of saints and sinners, of bold confessions of truth but also of the obstinate adoption of heresy, so the three ecumenical creeds had survived their many competitors because they stood the test of scriptural faithfulness. When things looked the darkest, and the truth seemed to be on the verge of extinction, there was nothing to fear, for Christians of all time, including Luther and his descendants, merely clung to the scriptural promises found in the creed: 'I believe in the holy Christian church, the communion of saints'.

It truly became an important Lutheran article of faith that both the Word and the Church will never perish (Headley 1963: 103). Luther wrote in his most famous hymn not only that 'The Word they shall allow to stand' but ends that verse with 'the kingdom ours remaineth' i.e., the Church will remain (Luther c.1528: 285). In the meantime, Lutherans use the Fathers, and cherish their help in interpreting Scripture, in witnessing to the faith, and in handing down salutary customs to the church-the church year, the liturgy, and the like. But they also use Christian discretion as they continue 
to study the Fathers of all periods, and practice true Christian freedom in adopting or adapting customs that are useful in building up God's people.

\section{Confessionalism Today}

The importance of written confessions to a healthy church is one of the most important Reformation inheritances that is now in danger of being lost. Not only are our Christian distinctives derided by secular culture, but unity is also the mantra among mainline denominations as well as among many evangelicals seeking a non-denominational base for joint activities. Cooperation can be useful in many ways, as when discussing specific topics like the recent fourteen articles of the 'Nashville Statement on Biblical Sexuality' - each with a robust 'We Affirm' and 'We Deny'. But when churches, i.e., worshipping communities, seek to unite on the basis of a simplistic gospel unity, the brief statements of faith that such groups usually produce give evidence of a theological anemia that would have horrified all of the Reformers. The 4,000 words of the Thirty-Nine Articles or the 12,000-word Westminster Confession require additions rather than contractions today. The modern theological situation has only become more complex in the past four centuries and articulating the truth will take longer rather than shorter documents. Depth is not merely a matter of knowledge, but of belief and practice. Knowing the full counsel of God and standing up for it against all comers is not always pleasant, and certainly is out of fashion. But to Luther and the Reformers it was the only godly stance and thorough and precise confessions were an important tool in doing just that.

Speaking all the truth, yet doing so in love with respect for those who disagree, can be done yet today. We need to model this in our churches before we can expect anyone to model it in politics or society. Sacrificing one's confessional heritage in the interests of tolerance is unnecessary, unproductive, and unbiblical. True tolerance involves understanding and respectfully interacting with the divergent opinions of others; it must not become silence or obsequious submission of one's own beliefs. Evangelical organizations such as the Evangelical Theological Society are most useful and productive when they facilitate a healthy debate on Scripture and its interpretation between those who adhere to a complete belief system, whether that is encapsulated in the Thirty-Nine Articles, the Westminster Confession, or any other confession. While many of those in free church traditions may see such confessions as theological straightjackets, Lutheran see them as norms-norms that have been normed (norma normata) by Scripture (the norma normans) to be sure; but still norms that can keep the church building God's kingdom solid and straight.

The lack of a historical sense, of a continuity with the early church, has led in part to an evangelical revival of interest in and study of the Fathers 
over the past three decades. Those who have taken part have found that such study also can help one avoid succumbing to the latest trends in theology and practice. Almost every new aberration is just a repackaging of an ancient heresy-Gnosticism, Montanism, Arianism, or Pelagianism, to name just the more common ones. If the heirs of the wider Reformation use the early church as Luther did, and remain confident in confessing its faith not only in the texts of the ancient creeds, but also those of the Reformation documents, there may yet be a revival in biblical confessionalism. To this Luther would have added a heartfelt, 'Amen. May it be so!'

\section{Bibliography}

AE-Luther, Martin (1955-1986) Pelikan J and Helmut L (eds) Luther's Works, American Edition, 54 vols. St. Louis: Concordia.

WA-Luther, Martin (1883-2009) D. Martin Luthers Werke (Weimar Ausgabe), 56 vols. Weimar: Hermann Böhlau.

WBr-Luther, Martin (1930-1970) D. Martin Luthers Werke, Briefwechsel (Weimar Ausgabe), 12 vols. Weimar: Hermann Böhlau.

WTr-Luther, Martin (1912-1921) D. Martin Luthers Werke, Tischreden (Weimar Ausgabe), 6 vols. Weimar: Hermann Böhlau.

(1516) Letter to George Spalatin, October 19 (AE 41:23-26; WBr 1: 70-71).

(1518) Introduction to A German Theology (AE 31:75-76; WA 1:378-379).

(1518b) Letter to Spalatin, Jan.18 (AE 48:52-55; WBr 1:133-134).

(1519) Leipzig Debate (WA 2:250-383).

(1521) Against Latomus (AE 32:137-260; WA 8:36-128).

(1522) Christmas Postille, Gospel for the Day of the Three Kings (AE 52:159-286; WA 10.1:555-728).

(1523) Sermon on the Creed, March 6 (WA 11:53-54).

(1528) Letter to Nicholas Gerbel, July 28 (AE 49:199-202; WBr 4:508, no. 1290).

(c.1528) A Mighty Fortress is Our God (AE 53:284-285; WA 50:455-457).

(1530) Letter no. 1674, to Melanchton, August 4 (WBr 5:525-527).

(1532) 'Introduction' to Athanasii libri contra idolatriam, ed. J. Bugenhagen.

Wittenberg (WA 30.3:530-532).

(1532) Table Talk,Veit Deitrich's edition: no. 347 (AE 54:49; WTr 1:140).

(1535) Sermon on Psalm 110, June 5 (WA 41:182-203).

(1535-38) Lectures on Genesis (AE 2; WA 42).

(1538) Preface to Galeatius Fapella's History (AE 34:275-278; WA 50:383$385)$.

(1538b) The Three Symbols or Creeds of the Christian Faith (AE 34:201229; WA 50:262-283). 
(1539) On the Councils and the Church (AE 41:9-178; WA 50:488-653).

(1545) Preface to the Latin Works of M. Luther (AE 34:323-338; WA 44:179-187).

Anderas P (2017, March 29) Martin Luther, Augustinianism, and Augustine. Oxford Research Encyclopedia of Religion. Ed. Retrieved 1 Dec. 2018, from http://oxfordre.com/religion/view/10.1093/acrefore/9780199340378.001.0001/acrefore-9780199340378-e-268.

Beer T and von Stockhausen A (1999) Die Disputation zwischen Arius und Athanasius: Luthers erste Klosterlektüre; ein Beitrag zur Lutherforschung. Weilheim-Bierbronnen: Institut für Lutherforschung der GustavSiewerth-Akademie.

Headley JM (1963) Luther's View of Church History. New Haven: Yale University Press.

Koehler W (1900) Luther und die Kirchengeschichte nach senen Scrhiften, Zunächst bis 1521. Erlangen.

Oberman H (1989) Luther: Man between God and the Devil. New Haven: Yale University Press.

Posset F (2003) The Front-Runner of the Catholic Reformation: The Life and Works of Johann von Staupitz. Burlington, VT: Ashgate.

Schulze M (1996) Martin Luther and the Church Fathers. In Backus I (ed) The Reception of the Church Fathers in the West: From the Carolingians to the Maurists. Lieden: Brill, pp. 573-626.

Steinmetz D (1981) Reformers in the Wings. Grand Rapids: Baker. 